\title{
Semiotic Analysis of The Labuh Saji Tradicional \\ Ceremony In Palabuhanratu Sukabumi, West Java
}

\author{
Tanjung Fauziah \\ Student, Arts Education, Yogyakarta State University \\ Indonesia \\ E-mail: tanjung0021pasca.2020@student.uny.ac.id \\ Dr. Dra. Kun Setyaning Astuti, M.Pd. (Corresponding author) \\ Lecturer, Arts Education, Yogyakarta State University \\ Indonesia \\ E-mail: kun_setyaningastuti@uny.ac.id
}

Received: November 30, 2021 Accepted: January 13, 2022 Published: January 23, 2022

doi:10.5296/ijch.v9i1.19422 URL: https://doi.org/10.5296/ijch.v9i1.19422

\begin{abstract}
Every community has its own distinct cultural characteristics. In a limited sense, it is frequently viewed as a custom or tradition, and is frequently demonstrated by traditional ceremonies. One such town is Palabuhanratu Sukabumi in West Java, which is noted for its small town atmosphere, attractive tourist sites, and a strong culture and customs. The Labuh Saji traditional ceremony is regarded as part of the local community's tradition.

The purpose of this research is to investigate and analyze the semiotic meaning of the Labuh Saji Traditional Ceremony in Palabuhanratu Sukabumi, West Java. The research method used was interpretive qualitative research, and in this study, semiotic research methods, specifically analytical methods, were used to evaluate the signs and meanings included in the object under investigation, which is the Labuh Saji Traditional Ceremony in Palabuhanratu.

According to the discussion, the Labuh Saji Traditional Ceremony in Palabuhanratu has a profound meaning, including the myths of the community that developed in Palabuhanratu, by carrying out the entire procession of the Labuh Saji traditional ceremony, which was shown to Almighty God and Nyi Mayang Sagara and is believed to avoid catastrophe,
\end{abstract}


calamity, and disaster. However, the surrounding community had changed a number of the offerings made during this traditional ceremony. However, many rituals and offerings continue to be practiced in accordance with established customs.

Keywords: culture, traditional ceremony

\section{Introduction}

Culture is a way of life that develops and is shared by a group of people and is passed down through generations (Wijaya, R and Aladdin, Y, 2015: 465). A cultural product depicts a traditional ceremony. Typically, traditional ceremonies are performed for specific objectives, such as prayer, wedding processions, and harvest celebrations. West Java Province is home to a variety of various traditional ceremonies. This traditional ceremony is still performed today. One of these is in West Java's Palabuhanratu Sukabumi region, where a traditional ceremony known as the traditional harbor ceremony is still carried out and maintained to this day. The ceremony is composed of numerous components that must be adhered to during its execution. Additionally, this traditional ceremony serves as a means of expressing thanks and shows the community's commitment to preserving their ancestral legacy. The Labuh Saji traditional ceremony, which continues to this day, cannot be isolated from its supporting elements, especially the community, as well as actors and artists who contribute to the preservation of cultural heritage.

Labuh Saji is a hereditary ceremony of Ratu Harbor fishermen to honor a princess named Nyi Putri Mayangsagara for her concern for fishermen's welfare. Since the 15th century, Mayangsagara has held the Labuh Saji ritual as an annual tradition in order to present offerings to the Queen of the South Seas, who was the ruler of the southern seas at the time. Mayangsagara performs the ceremony to ensure that fisherman benefit from their work.

On the basis of this history, the author wishes to convey and describe the elements that comprise the harbor's traditional ceremony, with a particular emphasis on the local community's myths and the meanings implicit in them. To determine the meanings contained, a more in-depth examination was conducted using Roland Barthes' semiotic theory of denotative and connotative meaning.

The study of signs in human existence is referred to as semiotics. Given that people are capable of giving meaning to a variety of sociocultural and natural occurrences, it is reasonable to conclude that signs are an integral aspect of human culture. Thus, semiotics is a branch of science concerned with the study of signs in daily life. The presence of semiotics enables us to view things differently. The term "signs" serves as the foundation for comprehending semiotics. Signs are omnipresent; anything can be a sign, and humans can think and communicate only via the use of signs. The sign serves as the foundation for all communication; humans can communicate with one another via the medium of signs. One of the most distinctive and interesting methods of communication is the art inherent in Palabuanratu's traditional anchoring ceremony.

The purpose of this study is to analyze a sign in the form of a myth and the significance of the traditional anchoring ceremony in Palabuhanratu. The purpose of this research is to reveal the 
meaning of connotation and denotation, as well as the hidden meaning.

\section{Methods}

The study analyzes the meanings and myths associated with the Labuh Saji traditional ceremony using Roland Barthes' semiotics method. As Roland Barthes proposed, cultural objects can be thought of as symbols of language or as a sign system that reflects the assumptions of a specific culture at a certain period (Vera in Wirianto and Girsang, 2016). A sign in a text or context can be analyzed using two elements, according to Roland Barthes' theory. The first type of analysis is connotative, while the second type is denotative.

The denotative meaning is the obvious meaning, or the true meaning. While the connotative meaning, or second layer, discloses the sign's concealed meaning.

Among the studies on denotation and connotation in this analysis point are the following: 1). The buffalo's head's meaning, 2). The Labuh Saji procession's meaning (buffalo head drifting) 3) The significance of sacrifices thrown into the sea; 4). Ham's meaning, 5). The meaning of the big four-color cone (Brown, White, Black, Yellow).

\section{Finding and Discussion}

\subsection{Labuh Saji Traditional Ceremony Procession}

According to the local community, Palabuhanratu is still dense with traditional rituals. Many ceremonies exist, notably Labuh Saji on Palabuhanratu beach, Sukabumi. The ritual is performed on a periodic basis to ensure that the ceremony is passed down from generation to generation. These myths are not historical truths or visible cultural objects, but rather serve as a catalyst for examination on their meaning. Mythology as reflective material depicts the style of thinking of the people in the area of Palabuhanratu in an indirect manner, which results in mystical thinking (Heryana. A, 2012: 157).

The Labuh Saji ritual is a tangible manifestation of the results of their ancestors' cultural civilization. This is because this ritual has existed since Nyi Ratu Mayang Sagara founded Palabuhanratu. Thus, the necessity for this activity must be carried on to future generations, given that the ritual has developed into a great cultural product as a result of its goal as an expression of appreciation for God's wealth of gifts. Simply put, the procedure is a communal effort to rid the living environment, particularly the coast and water, of anything that creates havoc. Additionally, there is hope, a desire, in this Labuh Saji tradition, to keep people away from undesirable situations. Additionally, there is a notion and belief that the sea has particular characteristics like as very huge waves and powerful winds, and that in order to avoid tragedy, the Labuh Saji ceremony custom is necessary.

Labuh Saji is composed of two fundamental elements. The first is "Labuh," which translates as "to float, throw, wash away, or start throwing something into the waterways, whether sea or river, while Saji / offerings refers to all agricultural products derived from earth products, both land and water. Thus, the Labuh Saji Ceremony is a way of showing thankfulness for humanity as God's creatures, expressed through floating or anchoring the earth's crops to the sea. As indicated previously, these types of processesions are frequently encountered and 
carried out in communities bordering the south coast, with varying ceremonial titles and traditions according to their individual localities. However, the anchoring ceremony must occur at the same time each year and the offerings must take the form of diverse foods; this requirement applies to any beach.

Prior to the Labuh Saji ceremony undergoing alterations, it was quite thick and filled with a very sacred impression, as seen by the numerous types of offerings, such as cones and buffalo heads, according to the pupuhu (special performer of the ritual). Because the offering's form serves as a magnet for mystical energies. Although implementation has not yet begun, preparations for the arrangement and gathering of offerings are mystical in nature, with the notion that tumpeng and buffalo heads will bring favors if offered to the sea through offerings. Additionally, when the Labuh Saji ceremony is performed, it is accompanied by the burning of incense with a highly distinct aroma, which transports the atmosphere immediately into the mystical realm through the recitation of mantras or spiritual prayers.

\subsection{The Structure of the Implementation of the Labuh Saji Traditional Ceremony}

The structure of the anchoring ceremony is inextricably linked to the form of something served, referred to as offerings. Saji means to serve anything; when it is suffixed with en, it turns to sajen, which means to give something in the form of food (sajen = caos dhahar). The purpose of making this offering can be interpreted in a variety of ways and has a variety of symbolic elements (Alkaf. M, 2013: 216). The funds necessary to prepare the offerings are raised through contributions from many fishing communities in Palabuhanratu that participate in the yearly Labuh Saji ritual, which has been passed down through generations. Each year, the community contributes funds to the realization of Labuh Saji by reserving their catch. The fishermen's catch is exchanged for rupiah, which is then given to the person selected and trusted to retain the monies. If there is insufficient funds to purchase buffalo and other needs like as rice offerings and decorations, there are still individuals eager to assist, most notably the owner of the taweu boat (big boat). If the taweu owners' costs are insufficient, they may purchase buffalo heads solely as a condition of carrying out the Labuh Saji Traditional Ceremony procession.

Given that the implementation occurs annually on April 6, the event is supported by all members of the community who carry out their responsibilities in accordance with their responsibilities. Buffalo are purchased approximately two or three days prior to slaughter. The purchase and preparation of all media or materials used in offerings involves the creation and decoration of dongdang (offering containers). Three dongdangs have been specially designed for their use. 1) Dongdang for storing buffalo heads, 2) Dongdang for storing various offerings, and 3). Dongdang for storing various offers. Dongdang is used to store various fruits and juada markets (food snacks for the local community) in the vicinity of Palabuhanratu.

This Labuh Saji ritual is magical; yet, it is subject to strict requirements and must be performed by members of the local community. Ceremonies considered sacred comprises four main components, including: (a) Physical form in the form of offerings, clothing, ritual performers, and other ceremonial items that accompany the procession, (b) 
The leader of the traditional ritual must be capable of ensuring the process's continuity, (c) The community's real activities in response to these customary rituals directed at things considered to contain hope, ideas, or meaning derived from a message transmitted by the community, (d) Cultural values, which are an idea or a thinking that has been instilled in the community's soul from an early age as part of the socialization process and serve as a basis for its existence.

In addition to the four main components mentioned above, in traditional rituals there are also other external factors that surround it, namely: (a) Sesajen preparation, sesajen preparation is the process of organizing sajen in the form of food, beverages, and heirlooms or sacred sites in order to acquire protection and magical powers from ancestral spirits through these heirlooms, (b) Supplication, asking for the safety, happiness, and mercy of God and ancestral spirits, which are found in heirlooms and places that are considered sacred, such as tombs, forests, seas, etc, (c) Pray, praying is concentrating the soul and emotions on a single point to discover the meaning of life and so bring about social peace, (d) Fasting, fasting is holding hunger for a certain period to purify yourself and strengthen the soul, (e) Communal eating, is a way of uniting the supernatural forces of ancestral spirits who perform rituals with the community surrounding the location of the ceremony, (f) Art, art is a presentation of many forms of art with the purpose of supporting the Labuh Saji event, (g) Parade, the parade involves transporting heirlooms and offerings around the place of worship for the magical force contained in the heirlooms and offerings to radiate and bring positive influence and security to the community and the areas through which the parade goes.

In the process, the main points of the Labuh Saji tradition are as follows: (a) Name of Ceremony, Labuh Saji is a practice in which people on the Palabuhanratu beach perform a ritual of floating or washing offerings in the water. This annual custom occurs on April 6 . This date in the Sukabumi Regency government's has become annual agenda, serving as both Fisherman's Day and the Day of the Labuh Saji traditional ceremony, (b) Ceremony Time, Three stages comprise the ceremonial activity:

- Pre-ceremony is an activity carried out at night before the implementation of the day.

- The second is when the ceremony takes place on April 6

- Third Post-ceremony, is an activity after the procession of offering offerings.

(c) Ceremony Venue, the place for the Labuh Saji celebration is precisely on Palabuhanratu beach, Sukabumi, West Java, (d) Ceremony Participants, the main participants of ceremony are the entire community, both the general public and the characters, with a handler typically leading the procession. The fishermen, in addition to performing the ceremony, act as carriers of dongdang, (e) Ritual Purpose, the offering parade's objective is to gather magical forces, the aura of offerings, and sacred power emanating from the paraded offerings. All offerings are made to ensure the individual performing this ritual's safety, happiness, and peace. This entails implying a community-accepted cultural value. Cultural value according to Uhi (in Hanif, 2016:134) is a general conception that is organized and can influence human behavior in relation to the natural and social environment, as well as with God. 
3.3 The Meaning of the Labuh Saji Traditional Ceremony in Denotation and Connotation

In this semiotic analysis, there are meanings of denotation and connotation in this traditional ceremony, including:

(a) The meaning of buffalo head.

Denotation: The buffalo head is a denotative symbol of great strength. The meaning is derived from the buffalo's philosophy, which is often similar with that of a tireless animal, as is the treatment of farming communities that employ buffalo to assist in plowing the fields.

Connotation: The local community regards the head of a buffalo as a sacred animal because it is the main offering included in the Labuh Saji ritual procession as an obligatory obligation. If these requirements are not met, an undesirable event will occur or a disaster will occur.

(b) The meaning of Labuh saji

Denotation: Labuh Saji is a tradition in which people on Palabuhanratu beach throw buffalo heads and offerings into the sea. This annual tradition occurs on April 6th. This day has been designated as Fisherman's Day or the day of the Labuh Saji ceremony on the Sukabumi Regency government's annual schedule.

Connotation: The buffalo head and the offerings made during this ceremony have a specific symbolism, which effectively translates as making an offering to Nyi Mayang Sagara. Besides of believe in God, traditional people believe in ancestral spirits, magical powers found in their natural environment, and heirlooms. Magical powers derived from nature and heirlooms are considered to be capable of bestowing blessings, balancing, and ensuring safety in life. They perform ceremonial rites to preserve the magical and supernatural powers of the surrounding nature and these heirlooms.

(c) The menaing of Sesajen

Denotation: Offerings are denotatively regarded as a required component that cannot be omitted from rituals they regard as sacred as a manifestation of obedience and respect for their ancestors' heritage.

Connotation: The offering is a representation of a type of offering to the gods, ancestral spirits, or spirits, as well as an accompaniment to prayers to the gods to obtain their wishes. Additionally, it is intended that they become comfortable and secure when performing the ceremony. Offerings are also a means of communication between humans and God Almighty.

(d) The meaning of Bakakak Hayam

Denotation: Bakakak hayam is typically served as a side dish or to complement rice, but it is also served as a component of offerings during traditional ceremonies.

Connotation: Bakakak hayam is interpreted as a necessary but not complementary requirement for traditional ceremonies. Apart from these meanings, Bakakak hayam represents the Sundanese people's main cultural values, as the food is regarded as a traditional dish that is 
always given at ceremonies. Bakakak hayam serves a societal purpose as a dish that proclaims unity.

(e) The Meaning of Four Colors in Tumpeng

Denotation: Tumpeng is interpreted in the form of rice that has four different colors (brown, white, black, yellow) which are then arranged into one cone-shaped.

Connotation: The four colors of the tumpeng imply a certain philosophy according to the color. The color depicts respect and hope for blessings from the four corners of the earth such as west, east, north and south.

\section{Conclusion}

Based on the discussion that has been provided, it can be stated that when holding a traditional ceremony, the Indonesian people's unique and characteristic customs and culture are on display. Among them is the ceremony that originated among the community of Palabuhanratu Sukabumi, Answerarat. This is a hereditary traditional ceremony performed by the surrounding community as a visible demonstration of communal behavior that upholds their ancestors' heritage. There is also a hope, a yearning, in the performance of the Labuh Saji traditional ceremony, that the community will avoid the calamity that befell them. Additionally, there is a notion and belief that the sea has specific qualities, such as particularly huge waves and strong winds, that are deemed unsafe for disasters to occur, and to avoid this, a Labuh Saji traditional ceremony is necessary. This ceremony is done annually on April 6 to commemorate Fisherman's Day. Additionally, other components or offerings of this ceremony are connected to the sea, including buffalo heads, various sorts of cones, special foods, incense, and other natural products. This ceremony is composed of four main components: (a) a physical manifestation in the form of offerings, (b) the responsibility of the ceremony's leader, (c) the community's attitude toward the Labuh Saji traditional ceremony, and (d) the cultural values inherent in the Labuh Saji ceremony. Along with the four main components, there are several other variables that contribute to the ceremony's success, including the following: (a) arrangement of offerings, (b) requests, (c) prayer, (d) fasting, (e) communal eating, (f) arts, and (g) parades. While the results of Roland Barthes' analysis of meaning in denotation and connotation in the Labuh Saji ceremony revealed that the meaning contained a certain philosophy, including (a) the meaning of a buffalo's head when viewed in denotation is a symbol of great power, when viewed in a denotative sense, the connotation of a buffalo head is considered a sacred animal by the local community due to its basic requirement, (b) The Labuh Saji ceremony is a denotative term that refers to the community's throwing of a buffalo head and offerings into the sea on the Palabuhanratu beach, whilst the connotative term refers to the rite as a sort of offering to Nyi Mayang Sagara. (c) While the denotative meaning of offers is viewed as a required component, the connotative meaning of offerings is interpreted as a symbol of a type of offering to the gods, spirits, or ancestor spirits, as well as the accompaniment of prayers. Addressing the gods in order for their aspirations to be approved, (d) The denotative meaning of Bakakak Hayam is supplementary food as side dishes, however the connotative meaning is that Bakakak Hayam is a complimentary food that is required for each ritual of the Labuh Saji ceremony. (e) the 
significance of four The cone's color is denotatively understood as rice with four distinct colors (brown, white, black, and yellow), which is then placed into a cone shape, while the connotative meaning of the cone's four colors denotes a particular philosophy. According to these findings, the Labuh Saji ceremony analysis reveals noble meanings that must still be embodied in the activities of the inhabitants of Palabuhanratu Sukabumi, West Java, in order to form relationships and maintain balance with nature and the species that coexist with them. Thus, it is not incorrect if the Labuh Saji ceremony is held annually, given that the ritual's underlying meaning for the community has been accepted as part of the tradition.

\section{References}

Alkaf, M. (2013). Berbagai Ragam Sajen Pada Pementasan Tari Rakyat Dalam Ritual Slametan. Gelar (Jurnal Seni Budaya), 11(2), 211-223. https://doi.org/10.33153/glr.v11i2.1469

Hanif, M. (2016). Kesenian Dongkrek (Studi Nilai Budaya Dan Potensinya Sebagai. Gulawentah Jurnal Studi Sosial (Journal of Social Science), 1(2), 132-141. https://doi.org/10.25273/gulawentah.v1i2.1036

Heryana, A. (2012). Mitologi Perempuan Sunda (Mythology of Sundanese Women). Patanjala, 4(1), 156-169. https://doi.org/10.30959/patanjala.v4i1.129

Hoed, B. H. (2014). Semiotik dan Dinamika Sosial Budaya. Depok: Komunitas Bambu. P.

Riwu, Asnat dan Pujiati, Tri. (2018). Analisis Semiotika Roland Barthes Pada Film 3 Dara $\begin{array}{llll}\text { (Kajian Semiotika). } & \text { DEIKSIS, } & \text { 212-223), }\end{array}$ https://dx.doi.org/10.30998/deiksis.v10i03.2809

St, S. (2002). Semiotika Negativa. Yogyakarta: Kanal.

Sugiarto, T. (2016). Desakralisasi Upacara Adat Labuh Saji. [Unpublished master's thesis]. Universitas Pendidikan Indonesia.

Wijaya, R. D. A., \& Yuri. (2015). Representasi Premanisme Dalam Film Jagal (Studi Semiotika Roland Barthes). Jurnal Semiotika, 9(2), 460-481. https://dx.doi.org/10.30813/s:jk.v9i2.23.g17

Wirianto, R. D. G., \& Lasmery, R. M. (2016). Representasi Rasisme Pada Film "12 Years A Slave" (Analisis Semiotika Roland Barthes). Jurnal Semiotika, 10(1), 180-206. https://dx.doi.org/10.30813/s:jk.v10i1.31

\section{Copyrights}

Copyright for this article is retained by the author(s), with first publication rights granted to the journal.

This is an open-access article distributed under the terms and conditions of the Creative Commons Attribution license (http://creativecommons.org/licenses/by/4.0/) 